\title{
NAPA Gene
}

National Cancer Institute

\section{Source}

National Cancer Institute. NAPA Gene. NCI Thesaurus. Code C126466.

This gene is involved in vesicular transport between the endoplasmic reticulum and the Golgi. 